\section{IJ§ER}

ISSN: 2149-5939
International Journal of Social Sciences and Education Research

Online, http://dergipark.gov.tr/ijsser

Volume: 3(2), 2017

\title{
Güven, iletişim ve empati bağlamında ilişkisel pazarlamanın tüketici temelli marka değerine etkisi: GSM operatör kullanıcıları üzerinde bir uygulama
}

\author{
The effect of relationship marketing in the context of trust, communication and \\ empathy to customer based brand equity: An application on GSM sector users
}

\author{
Abdulbaki Baran1 Ercan Tașkın²
}

Received Date: $01 / 09$ / 2016

Accepted Date: 15 / $01 / 2017$

$\ddot{O} z$

İsletmeler artan rekabet ortamında sürdürebilir rekabet avantajı oluşturmak için müssterileriyle etkili bă̆ kurup müşteri kayıplarını azaltmayı hedeflemektedir. İsletme bununla kısa dönemde sağlayacağı karın yerine daha çok kar elde edecek uzun vadeli bir ilișkiyi amaçlar. İlişkisel pazarlamayla tüketicilerin zihinlerinde olumlu bir imaj oluşturacak güven, empati, taahhüt ve iletişim unsurları müşterilerle işletme arasında etkili bir ilişki meydana getirir. Işsletmenin sağladı̆ $\breve{l}$ bu ilişkiler işletmeyi hem tüketici için vazgeçilmez kılar hem de motive etmektedir. Bunun sonucunda işletmenin marka bilinirliliği, çăgrışımı, sadakati ve kalite algısı artacaktır. İsletmenin kendi markasıyla oluşturduğu bu birliktelik müşsteride algllanan marka değerini etkileyip müşteri sadakatini oluşturacaktır. Müşteri sadakati ile marka karşısında diğer alternatiflerin gücü azalacak, tüketicinin algıladığı marka değeri yüksek olan markayla birliktelik oluşturarak müşteri olmanın getirdiği maliyetlerin azalmasına sebep olacaktır. Bununla beraber tüketici çevresindekilere marka hakkında olumlu tecrübelerini aktararak işletmeye yeni müşterilerin kazanılmasına yardımcı olur. Bu amaçla gerçekleştirilen çalışmada Dumlupınar Üniversitesi İktisadi ve İdari Bilimleri Fakültesinde ögrenim gören 267 GSM kullanıcısından elde edilen veriler analiz edilerek ilişsisel pazarlama uygulamalarının tüketicilerin algıladı̆̆ı marka değerini ne derece etkilediği tespit edilmeye çalışılmıştır. Elde edilen sonuçlar, iletişimin marka değerinin üç boyutu olan marka çağrışımı, marka sadakati ve algılanan kalite üzerinde anlamlı etkiye sahipken, empatinin ise marka çă̆rışımı ve algılanan kaliteyi anlamlı olarak etkilediğini göstermiştir. Ancak güvenin marka değeri boyutları üzerinde anlamlı bir etkisinin olmadı̆̆ sonucuna ulaşılmıştır.

Anahtar Sözcükler: Illişkisel pazarlama, marka dĕgeri, pazarlama

\section{Abstract}

Firms aim to create a strong connection with the customer to decrease customer losses in order to have a sustainable competitive advantage in an increasingly competitive environment. A firm's target with this strategy is to have long term relationship which will bring a greater profit, rather than short term. With relationship marketing; trust, empathy, commitment in the minds of customers and communication factors create an effective communication between customers and the firm. This relationship created by the firm, not only makes the firm essential for the customer, but also motivates the customer. As a result of this, brand awareness, association of the brand, loyalty to the firm and quality perception will improve. This uniformity of the brand and the firm will affect perceived brand equity and therefore will create brand loyalty. Thanks to brand loyalty, attractiveness of the other alternatives against the brand will decrease, therefore costs of being a customer will decrease as customer creates a uniformity with the brand which is perceived as high brand equity. In addition to this, customer will share their positive experiences about the brand with their kith and kin and will help the brand to gain new customers. In this regard, the data obtained from 267 GSM users studying at the Faculty of Economics and Administrative Sciences of Dumlupinar University were analyzed and it was tried to determine to what extent the relationship marketing applications affected the brand equity perceived by customers. The results show that empathy has a significant effect on brand associations and perceived quality, while communication has a significant effect on brand associations, brand loyalty and perceived quality which are the dimensions of brand equity. However, trust has been reached that there is no meaningful effect on brand equity dimensions.

Keywords: Relationship marketing, brand equity, marketing

\footnotetext{
${ }^{1}$ Dumlupınar Üniversitesi, Kütahya, Türkiye, abaki.baran@dpu.edu.tr

${ }^{2}$ Dumlupınar Üniversitesi, Kütahya, Türkiye, ercan.taskin@dpu.edu.tr
} 
Baran, A. (2017). Güven, iletişim ve empati bağlamında ilişkisel pazarlamanın tüketici temelli marka değerine etkisi: GSM operatör kullanıcıları üzerinde bir uygulama. International Journal of Social Sciences and Education Research, 3(2), 361-378.

\section{Teorik çerçeve ve literatör taraması}

\subsection{Illişkisel pazarlama}

İlişkisel pazarlama terimi ilk Bery ile başlanmış ve Jackson'la işletmeler kapsamında kullanılmıştır. 1990'lı yıllarda tüketicilerde artan bilgi düzeyi ve fiyat duyarlılığıyla beraber ürünlerdeki ayırt edici unsurların azalmasıyla bu dönemde ilişkisellik kavramı ön plana çıkmaya başlamıştır. Yeni başlayan etkileşimli iletişim yaklaşımı ilişkileri cazip hale getirilip tüketicilerle uzun vadede sürdürmek istemişlerdir (Selvi, 2007). İlişkisel pazarlama, tüketici ve diğer ortaklarla kurularak ilişkilerin bütün bireylerin istek ve amaçlarının tanımlanması, sürdürülmesi ve geliştirilmesi temeline dayanmaktadır. İlişkisel pazarlamayla tüketicilerin tutum ve davranışlarına etki ederek memnuniyeti sağlamaya yönelik kalite algısı üzerinden müşterilerin gelecek ürün alımlarına etki etmeye yönelik çabalardır (Grönroos, 1996).

İlişkisel pazarlamanın uygulanabilmesi için işletmenin iç ve dış unsurlarının ilişskisel pazarlama anlayışını benimsemesi gerekmektedir. Bu anlayış işletmenin müşteri odaklı olması ve uyumlu olmasıyla fayda sağlayacaktır (Yurdakul ve Dalkılıç, 2006). Evert Gummesson, ilişkisel pazarlamayı; "bilgi ağları ve karşılıklı etkileşimle oluşan ilişkiler" şeklinde ifade ederek teknolojinin ilişkisel pazarlamayla sağlanan etkileşimle müşterilere daha yakın olunacağını söylemektedir (Gülmez ve Kitapçı, 2003). İlişkisel pazarlama, rakiplerin arttı̆̆ı ve müşterilerin daha çok değer kazandığı müşteri kraldır savını savunan modern pazarlama anlayışıdır. Müşteriler işletmelerin varlıklarının devamını sağlayan unsurlar olduğundan işletmenin bir parçası olduklarını hissettirilmesi gerekmektedir. Müşteriye verilen kıymet hem müşteri memnuniyetini hem de müşteri sadakatini ortaya çıkarmaktadır (Gülmez ve Kitapçı, 2003). Dolayısıyla temel amaç müşterilerle uyum ve iş birliğinin temel almaktır (Sheth and Parvatiyar, 2000). İlişkisel pazarlama, müşterilerle bağlılığın ve güvenin sağlanmasında ve bununla beraber pazarlama etkinliği ve verimliliğini arttırması açısından önemli hale gelmiştir (Kılıç ve Erdoğan, 2016). Bu çalışmada ilişkisel pazarlamanın güven, bağ lılık, iletişim ve empati olmak üzere dört boyutu ele alınacaktır.

Güven: Güven bir işletmenin hizmet sağlayıcıları hakkındaki pozitif beklentidir. Güven için en önemli unsur niyettir. Güvende elde edilen faydaların müşteri sadakatine doğrudan etkisi ve güçlü bir şekilde etkilemektedir (Selvi, 2007). İşletmelerine ve markalarına güvenen müşteriler işletmeleriyle kurdukları ilişki düzeyini sürekli devam ettirirler (Hacıefendioğlu ve Çolular, 2008)

Bağlllık: İliş̧ki kalitesinin en önemli unsuru olan bağlılık, alıcı ve satıcının istenen amaca birlikte hareket etmesiyle oluşan iş ilişkisi bileşenidir (Selvi, 2007). Bir ürün yada hizmetin sunulmasında taraflar arasında çıkabilecek sorunların üstesinden gelmek ve ilişkinin devamının vurgulanması başarılı bir adımdır (Morgan and Hunt, 1994).

Illetişim: Duygu, düşünce, bilgi ve becerilerin karşılıklı olarak etkileşim süreci olarak ifade edilmektedir. Başarılı bir etkileşimin sağlanmasında verilen mesajın hedef kitleye doğru kanallarla ulaşılması önem kazanmakta ve mesajın iletileceği araçların saptanması ve geri bildirimin alınmasına bağlı olarak tamamlanmış süreci ifade etmektedir (Taşkın vd., 2014).

Empati: İki tarafın bir durum karşısında birbirlerinin bakış açısıyla olayı görebilmeyi sağlayan bir bileşendir. Empati ilişki sürecinde başka birinin istek ve amaçlarını anlama becerisi olarak ifade edilmektedir (Sin vd., 2005). 
Baran, A. (2017). The effect of relationship marketing in the context of trust, communication and empathy to customer based brand equity: An application on GSM sector users. International Journal of Social Sciences and Education Research, 3(2), 361-378.

\subsection{Tüketici temmelli marka değeri}

Tüketici temelli marka değeri; pazarlama faaliyetleri sonucunda oluşturulan soyut bir unsur olarak tüketicilere sunulan ürün ve hizmetlerin değerini azaltan ya da artıran, markanın sembol ve isim gibi farklı özelliklere sahip bileşenlerin tamamını tanımlamaktadır (Aaker, 1991). Vazquez vd. (2002), tüketicilerin markanın kullanılması ve bununla beraber elde ettiği sembolik ve fonksiyonel faydaların tamamını tüketici temelli marka değeri olarak tanımlamaktadır. Marka değeri bileşenleri; marka imajı, markaya güven, markadan etkilenme, marka farkındalığı, markaya ilişkin çağrışımlar ve marka bağlılığı unsurlarını kapsamaktadır (Keller, 1993). Marka fiziksel olmayan varlıklarının değeri fiziki varlık değerlerinin kat kat aşan değerlere ulaşmıştır (İlgüner, 2009). Aaker (1991) modelinde marka değeri boyutlarını; marka bağlılığ1, algılanan kalite, marka farkındalığı ve marka çağrışımı olarak belirtmiştir.

Marka Farkındalığ l: Markaya dair tüketiciye bir bilgi verildiğinde tüketicinin önceki bilgileri hatırlayıp kullanabilme yeterliliğidir (Pappu vd., 2006). Marka değerinin oluşturulmasında önemli faktörlerdendir. Bir marka pazarda eriştiği hatırlanma düzeyi yüksekse satın alma niyetini, markaya ilişkin alg1 ve tutumları olumlu şekilde etkiler (V1llajero, 2009). Günümüzde yoğun rakiplerin arasında markaların kaybolması marka farkındalığının ne kadar önemli olduğunu göstermektedir. Rakipler arasında marka farkındalığı ile sıyrılması Pazar performansı üzerinde olumlu etliye neden olur (Homburg vd, 2010).

Marka Çă̆rışımları: Marka çağrışımlarının en önemli özelliği bilinç altına hitap etmesidir. Marka ilişkili deneyimlerin değerlendirilmesinde marka duyguları sözsüz veya sinirsel olarak görülür. Bununla beraber marka çağrışımları tüketici hafızasında duygusal etkiler olu (Supphellen,2000). İşletmeler markaya karşı pozitif tutumlar yaratmada, markayı farklılaştırma ve genişletme çalışmalarında, konumlandırmada ve herhangi bir markanın satına alınmasında ve sağlanan faydanın ifade edilmesinde marka çağrışımlarını kullanmaktadırlar (Low and Lamb, 2000).

Marka Sadakati: Markaya bağlı tüketici grubudur. Keşfettikleri markanın kullanıcısı olmanın hazzını yaşayan tüketici grubudur. Kullandıkları markaları kendilerinin ifadesi olarak görürler. Markaya sadık tüketiciler, başkalarını ya da pazarı etkileyerek işletmeden daha fazla değer yaratırlar (Aaker, 1991). Etkili marka sadakatini oluşturan markalar yüksek fiyatlar ve daha geniş pazar paylarına sahip olabilmektedirler (Ayas, 2012).

Algılanan Kalite: İşletmenin ürettiği gerçek kalite değildir fakat ürünün sübjektif olarak değerlendirmesi sonucunda ürün performansı yada mükemmelliği hakkındaki soyut yargılardır (Parasuraman vd., 1988). Doney ve Cannon (1997)'a algılanan kaliteyle oluşan güven, rekabet üstünlügü sağlamakta, işlem maliyetlerini azaltmakta ve değer yaratmaktadır. Zeithalm (1988), algılanan kalitenin, değerin algılanmasına katkı sağladığını ifade etmektedir.

\subsection{Illişkisel pazarlama ve tüketici temelli marka değeri}

İlişskisel pazarlamayla marka arasında ilişki ağının oluşturulması ve bu ilişkinin geliştirilmesi markada algıladığı maliyeti en aza indirgemektedir (Erdoğan ve Torun, 2009). Tüketiciye yönelik ilişkilerin artırılması ve tüketici davranış ve amaçlarının anlama markaya yönelik aitlik sağlayarak güven oluşturmaktadır (Flavian, 2005). İlişsisel pazarlama uzun dönemli değişim ilişkilerine odaklanmaktadır. Bunun 1şığında marka değeri bileşenlerinden marka sadakatin, uzun dönemli ilişkiler kurulması ve sürdürülmesinde önemli bir unsur olmaktadır (Torlak vd., 2014). 
Baran, A. (2017). Güven, iletişim ve empati bağlamında ilişkisel pazarlamanın tüketici temelli marka değerine etkisi: GSM operatör kullanıcıları üzerinde bir uygulama. International Journal of Social Sciences and Education Research, 3(2), 361-378.

İlişki düzey kalitesinin güçlü ve müşteri memnuniyetinin yüksek olduğu işletmeler etkili bir marka değeri sağlamış olur.

Morgan and Hunt (1994), tüketicilerin markaya güvenmesi zaman içinde müş̧eri ilişkilerin kurulmasına yönelik atılmış anlamlı bir adımdır. Jesri vd. (2013), yaptığı çalışmada bağlılık ve güvenin marka sadakati üzerinde bir etkisi olduğu sonucuna ulaşmıştır. Aaker ve Jacobson (1994), işletmeler hizmetlerin üretilmesinde ve bunun tüketiciye sunulmasında uzun vadede müşteri ilişkilerinin geliştirilmesine yönelik zihinde algılanan kaliteyi güçlü bir şekilde gerçekleştirmesi gerekmektedir. Abeysekera and Wickramasinghe (2013), cephe hattındaki çalışanların ilişki odaklı olmaları, müşteri açısından markaya yüksek bir değer algılanması yapılarak olumlu bir imaj oluşturulur. Wolter (2009), müsşterilerle oluşturulan güven zaman içerisinde ürünün tekrar satın alınması, marka bilinirliliğine, marka sadakatini ve marka çağrışımını artırır. Bu da ağızdan ağıza yoluyla başka tüketicilere ulaşılarak işletmeye bir motive unsuru olur. Aynı zamanda işletme çalışanlarının müşteriyi kral olduğunu hatırlatması ve bu değeri sunması markaya olan bağlılığ ve algılanan kaliteyi artıracaktır. Bundan dolayı ilişkisel pazarlama ile marka değeri arsında pozitif bir ilişki vardır. Ukkwatte ve Abeysekera (2015), otele gelen müşteriler üzerinde yaptığ çalışmada ilişkisel pazarlamanın marka değeri üzerinde olumlu bir etkisi olduğu sonucuna ulaşmıştır. $\mathrm{Bu}$ sonucun sürdürebilir rekabet avantajı sağladığını ifade etmektedir. Yoganathan (2015), bankalar üzerinde yaptığı çalışmada ilişkisel pazarlama oryantasyonunun marka değeri gelişimini olumlu etkilediğini savunmuştur. İlişkisel pazarlama oryantasyonu boyutlarının güven, iletişim, ortak değerler ve empatinin marka değerinin olumlu etkisi sonucuna ulaşmıştır.

\section{Yöntem}

Araştırmada kullanılan anket formunda marka değeri için Aaker (1991) yaptığı çalışmadan uyarlanmıştır. İlişkisel pazarlama ölçeği ise Abdullah ve Kanyan (2012)'nın çalışmasından dört boyut uyarlanarak hazırlanmıştır. Anket formun birinci kısmında demografik özellikler, ikinci kısımda marka değeri değişkenleri ve üçüncü kısımda da ilişkisel pazarlamanın değişkenlerine ilişkin 5'li likert ölçeği (1-Kesinlikle Katılmıyorum...5-Kesinlikle Katılıyorum) soruları yer almaktadır. Anket çalışması için seçilen ana kütleyi Dumlupınar Üniversitesi İktisadi ve İdari Bilimler Fakültesinde eğitim gören öğrenciler oluşturmaktadır.

\subsection{Araştırma evreni ve örneklemi}

Çalışmamızın ana kütlesini Dumlupınar Üniversitesi'nde 2016-2017 yılı Güz Döneminde İktisadi ve İdari Bilimler Fakültesinde aktif olarak eğitim gören 9.944 (DPÜ Öğrenci İşleri, 2016), öğrenciden oluşmaktadır. Ana kütlede yer alan kişilerin örneklem içerisine dahil edilmesinde Kolayda örnekleme yönteminden yararlanılmıştır. Çalışmada 295 kişiye ulaşılmıştır. Elde edilen anketler değerlendirildiğinde 28 anket eksik, hatalı ve gerçekçi doldurulmadığı düşünüldüğünden analize dahil edilmemiştir. Kalan 267 anket üzerinde gerekli analizler yapılmıştır.

\subsection{Araştırmanın amacı ve klsitları}

Araştırmanın amacı, ilişkisel pazarlama boyutlarının marka değeri boyutları üzerine etkisini belirlemektir. Bu doğrultuda ilişkisel pazarlama boyutlarının tüketici tarafından algılanan marka değeri boyutlarıyla ne düzeyde etkilediği sonucu incelenmesi amaçlanmıştır. Araştırmanın kapsamını, üniversite öğrencileri oluşturmaktadır. Araştırmanın en büyük kısıtı çalışmanın bir ilde bir fakültede bulunan öğrencilere yönelik yapılacak sonuçların genellenebilirliliğinin ortadan 
Baran, A. (2017). The effect of relationship marketing in the context of trust, communication and empathy to customer based brand equity: An application on GSM sector users. International Journal of Social Sciences and Education Research, 3(2), 361-378.

kalkmasıdır. Araştırmaya katılan operatör kullanıcılarının kendilerine yöneltilen sorulara samimi ve doğru cevap verdikleri kabul edilmiştir.

\subsection{Araştırmanın veri toplama araçları}

Araştırmada gerekli olan verilerin toplanması için, birincil veri toplama yöntemlerinden olan anket yönteminden faydalanılmıştır. Anketin uygulanmasında yüz yüze anket tekniğinden yararlanılmıştır. Örnek kütleden toplanacak veriler için hazırlanan anket metni marka değeri, ilişkisel pazarlama ve demografik bulguları ortaya koyacak sorulardan meydana gelmektedir. Hazırlanan anket formunda anlaşılmayan ifadelerin olacağı ve güvenirliğin sağlanıp sağlanamayacağ düşünülerek 55 kişilik bir grup üzerinde pilot çalışma yapılmış pilot çalışmada sonucuna göre anket formunda ifadelerin anlaşılmasında genel bir problem olmadığı bununla birlikte güvenirliğinin uygun değerde çıktığı görülmüştür.

\subsection{Araştırmanın modeli ve hipotezleri}

Bu bölümde araştırmamızın temelini oluşturan ve Şekil 1'de gösterilen araştırma modelinde kullanılan değişkenler ve bunlar arasındaki ilişkiler açıklanmaya çalışılmıştır. Bu doğrultuda çalışmamızın hipotezleri geliştirilmiştir.

Şekil 1. Araştırma modeli

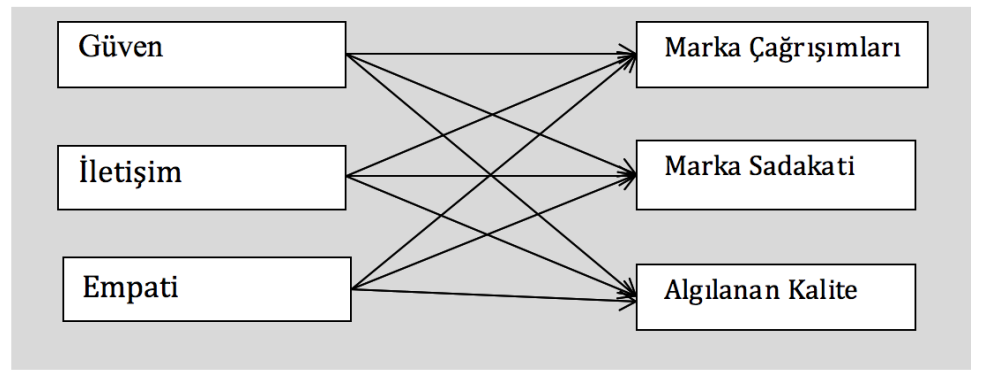

Araştırmanın amaç ve kapsamı çerçevesinde geliştirilen hipotezleri;

$\mathrm{H}_{1}$ : İlişkisel Pazarlama boyutlarından Güven, Marka Çağrışımlarını pozitif yönde ve anlamlı olarak etkilemektedir

$\mathrm{H}_{2}$ : İlişkisel Pazarlama boyutlarından İletişim Marka Çağrışımını pozitif yönde ve anlamlı olarak etkilemektedir

$\mathrm{H}_{3}$ : İlişkisel Pazarlama boyutlarından Empati, Marka Çağrışımlarını pozitif yönde ve anlamlı olarak etkilemektedir

$\mathrm{H}_{4}$ : İlişkisel Pazarlama boyutlarından Güven, Marka Sadakatini pozitif yönde ve anlamlı olarak etkilemektedir

$\mathrm{H}_{5}$ : İlişkisel Pazarlama boyutlarından İletişim, Marka Sadakatini pozitif yönde ve anlamlı olarak etkilemektedir

$\mathrm{H}_{6}$ : İlişkisel Pazarlama boyutlarından Empati, Marka Sadakatini pozitif yönde ve anlamlı olarak etkilemektedir

$\mathrm{H}_{7}$ : İlişkisel Pazarlama boyutlarından Güven, Algılanan Kaliteyi pozitif yönde ve anlamlı olarak etkilemektedir

$\mathrm{H}_{8}$ : İlişkisel Pazarlama boyutlarından İletişim, Algılanan Kaliteyi pozitif yönde ve anlamlı olarak etkilemektedir 
Baran, A. (2017). Güven, iletişim ve empati bağlamında ilişkisel pazarlamanın tüketici temelli marka değerine etkisi: GSM operatör kullanıcıları üzerinde bir uygulama. International Journal of Social Sciences and Education Research, 3(2), 361-378.

$\mathrm{H}_{9}$ : İlişkisel Pazarlama boyutlarından Empati, Algılanan Kaliteyi pozitif yönde ve anlamlı olarak etkilemektedir

\section{Bulgular}

\subsection{Betimleyici istatistiksel bulgular}

Betimleyici istatistiksel analizler doğrultusunda, araştırmaya katılan kişilerin cinsiyet, yaş, bulunduğu sınıf, kullandığı operatör, gelir, başka operatöre geçme isteği ve operatörün sosyal medyada takip etme özelliklerine ilişkin bulgular Tablo 1'de detaylı olarak verilmiştir.

Tablo 1. Ankete katılanların demografik değişkenlere ilişkin frekans dağılımı

\begin{tabular}{|l|l|l|}
\hline \multicolumn{2}{|c|}{ Değişken } & Frekans \\
\hline \multirow{4}{*}{ Cinsiyet } & Kadın & 164 \\
& Erkek & 103 \\
\hline & 18 ve altı & 24 \\
Yaş & $19-21$ & 160 \\
& $22-24$ & 77 \\
& 25 ve üstü & 6 \\
\hline \multirow{5}{*}{ Sınıf } & 1 Sinıf & 65 \\
& 2 Sinıf & 41 \\
& 3 Sinıf & 93 \\
Kullandığınız operatör & 4 Sinıf & 68 \\
& Turkcell & 48 \\
& Vodafone & 118 \\
Gelir & Türk Telekom & 89 \\
& Diğer & 12 \\
\hline \multirow{2}{*}{ Başka operatöre geçmek ister misiniz? } & 500 TL ve altı & 109 \\
& 501 TL- 1000 TL & 105 \\
Operatörünüzü sosyal medya & Evet & 35 \\
üzerinden takip ediyor musunuz? & Hayır & 18 \\
\hline & Evet & 59 \\
& Hayır & 208 \\
\hline
\end{tabular}

\section{2. Ölçeklere ilişsin faktör analizi ve güvenilirlik analizi sonuçları}

Marka değeri ölçeği faktör analizi: Ölçeğin geçerliliğini kanıtlamak amacıyla yapılan açıklayıcı faktör analizi sonucunda Kaiser-Olkin-Mayer (KMO) değerinin 0,80 olduğu tespit edilmiştir. Bu değerin 0,5'in üstünde olması örneklem büyüklüğünün faktör analizi için uygun olduğunu göstermektedir. Aynı şekilde, Bartlett küresellik testi (Yaklaşık =700,858; SD=45) değeri de 0,000 düzeyinde anlamlı olarak hesaplanmıştır. Bu da verilerin faktör analizine uygun olduğunu doğrulamaktadır. Analiz sonucunda düşük faktör yüklerine sahip olan ve iki faktöre yüklenen ifadeler analizden çıkarılarak kalan 10 ifade ile değerlendirmeler gerçekleştirilmiştir. Varimax yöntemi ile elde edilen, döndürülmüş bileşen matrisi Tablo 2'de gösterilmektedir. 
Baran, A. (2017). The effect of relationship marketing in the context of trust, communication and empathy to customer based brand equity: An application on GSM sector users. International Journal of Social Sciences and Education Research, 3(2), 361-378.

Tablo 2. Marka değeri alt boyutlarını belirlemeye yönelik faktör analizi sonucu

\begin{tabular}{|c|c|c|c|}
\hline & \multicolumn{3}{|c|}{ Faktör } \\
\hline & 1 & 2 & 3 \\
\hline 13Kullandığım operatör hizmetlerine her yerden ulaşabilirim. & 657 & & \\
\hline $\begin{array}{l}\text { 14Kullandığım operatör reklamları sayesinde rakipleri arasından } \\
\text { hemen tanırım. }\end{array}$ & ,793 & & \\
\hline 15Kullandığım operatörün hizmetlerini betimleyen kelimeleri vardır. & ,791 & & \\
\hline $\begin{array}{l}\text { 2Kullandığım operatör markası ile sorun yaşasam dahi başka marka } \\
\text { almam. }\end{array}$ & & 843 & \\
\hline $\begin{array}{l}\text { 4Başka GSM operatörleri çıksa dahi her zaman kullandığım oper- } \\
\text { atörün hizmetini kullanırım. }\end{array}$ & & ,814 & \\
\hline 3Kullandığım operatör hizmetini herkese tavsiye ederim. & & & ,550 \\
\hline 9Kullandığım operatör hizmetini kaliteli olduğu için satın alırım. & & & ,788 \\
\hline $\begin{array}{l}\text { 10Rakip markalar ile kıyaslandığında kullandığım operatör güçlü } \\
\text { marka imajına sahiptir. }\end{array}$ & & & ,781 \\
\hline 12Kullandığım operatör hizmetlerinin kalitesi yüksektir. & & & ,728 \\
\hline 17Kendimi Kullandığım operatöre daha yakın hissederim. & & & ,543 \\
\hline Cronbach $\alpha$ Değeri & ,673 & ,683 & ,778 \\
\hline Açıklanan Varyans & $\% 18,701$ & $\% 16,964$ & $\% 25,422$ \\
\hline Toplam Açıklanan Varyans & & $\% 61,088$ & \\
\hline
\end{tabular}

Tablo 2'de faktör analizinin sonucunda ortaya çıkan faktörler ve bu faktörlerin toplam varyansın ne kadarını açıkladığı görülmektedir. Buna göre, 1. faktör varyansın \% 18,701'ini, 2. faktör \% 16,964'ünü ve 3. faktör \%25,422'sini açıklamaktadır. Ölçeğin Marka değerini üç faktörlü olarak açıklama düzeyi ise \%61,088 dir. Ölçekteki faktörlerin güvenilirlik (iç tutarlılık) katsayıları ise sırasıyla; Marka Çağrışımları: 0,673, Marka Sadakati: 0, 683 ve Algılanan Kalite: 0, 778 olarak bulunmuştur. Bunun yanında dördüncü faktör olan ve üç ifadeden oluşan Marka Farkındalığ (0.348) düşük güvenirlikte olmasından dolayı değerlendirmeye tabi tutulmamıştır.

İlişkisel pazarlama ölçeği faktör analizi: Ölçeğin geçerliliğini kanıtlamak amacıyla yapılan açılayıcı faktör analizi sonucunda Kaiser-Olkin-Mayer (KMO) değerinin 0,94 olduğu tespit edilmiştir. Bu değerin 0,5'in üstünde olması örneklem büyüklüğünün faktör analizi için uygun olduğunu göstermektedir. Aynı şekilde, Bartlett küresellik testi (Yaklaşık =3917,113; SD=276) değeri de 0,000 düzeyinde anlamlı olarak hesaplanmıştır. Bu da verilerin faktör analizine uygun olduğunu doğrulamaktadır. Analiz sonucunda düşük faktör yüklerine sahip olan ve iki faktöre yüklenen ifadeler analizden çıkarılarak kalan 24 ifade ile 3 boyutta (güven, bağl1lık, iletişim) değerlendirmeler gerçekleştirilmiştir. Varimax yöntemi ile elde edilen, döndürülmüş bileşen matrisi Tablo 3'de gösterilmektedir. 
Baran, A. (2017). Güven, iletişim ve empati bağlamında ilişkisel pazarlamanın tüketici temelli marka değerine etkisi: GSM operatör kullanıcıları üzerinde bir uygulama. International Journal of Social Sciences and Education Research, 3(2), 361-378.

Tablo 3. İlişkisel pazarlamanın alt boyutlarını belirlemeye yönelik faktör analizi sonucu

\begin{tabular}{|c|c|c|c|}
\hline & \multicolumn{3}{|c|}{ Faktör } \\
\hline & 1 & 2 & 3 \\
\hline 10Kullandiğım operatörün sözlerine güvenilmektedir. & ,749 & & \\
\hline $\begin{array}{l}12 \text { Kullandığım operatör müşteriye her zaman doğru bilgiyi aktarmak- } \\
\text { tadır. }\end{array}$ &, 740 & & \\
\hline 11Kullandığım operatörün verilen hizmetlerine güven duyulmaktadır. & ,673 & & \\
\hline 8Kullandığım operatör, müşteriye dürüst ve samimi olmaktadır. & ,658 & & \\
\hline 9Kullandığım operatör, müşteri ile rahat ilişki kurmaktadır. & 619 & & \\
\hline 15Kullandığım operatör, önemli şeylerde güvenilir olmaktadır. & ,603 & & \\
\hline $\begin{array}{l}25 \text { Kullandığım operatör e, makul fiyata mükemmel ürün ve kaliteli } \\
\text { hizmet sağlamaktadır. }\end{array}$ & & ,714 & \\
\hline 24 Kullandığım operatör, en iyi hizmeti vermeye kendini adamaktadır. & & ,712 & \\
\hline $\begin{array}{l}21 \text { Kullandığım operatör, hizmetini müşterinin ihtiyaçları doğrul- } \\
\text { tusunda olup, isteklerini karşılamaktadır. }\end{array}$ & & ,706 & \\
\hline $\begin{array}{l}26 \text { Kullandığım operatör, müşteri geribildirimlerine değer verip, hiz- } \\
\text { met kalitesini artırmak için geribildirimleri kullanmaktadır. }\end{array}$ & & ,694 & \\
\hline $\begin{array}{l}23 \text { Kullandı̆̆ım operatör, müşteri ile uzun süreli ilişkiler kurup, devam } \\
\text { ettirmektedir. }\end{array}$ & & 667 & \\
\hline $\begin{array}{l}31 \text { Kullandığım operatör kaliteli hizmet vermede devamlılık sağla- } \\
\text { maktadır. }\end{array}$ & & 655 & \\
\hline $\begin{array}{l}28 \text { Kullandığım operatör, anlaşmazlıkları etkin bir şekilde çözmekte- } \\
\text { dir. }\end{array}$ & & ,627 & \\
\hline 19 Kullandığım operatör, hızlı hizmet vermektedir. & & ,622 & \\
\hline $\begin{array}{l}27 \text { Kullandığım operatör, müşteriye nasıl bir yaklaşımda bulunacağını } \\
\text { bilmektedir. }\end{array}$ & & ,616 & \\
\hline $\begin{array}{l}20 \text { Kullandığım operatör, görevlerini sorumluluk içerisinde } \\
\text { gerçekleştirmektedir. }\end{array}$ & & ,602 & \\
\hline $\begin{array}{l}17 \text { Kullandığım operatör, sorulara yanıtlayabilecek bilgi ve yetkinliğe } \\
\text { sahiptir. }\end{array}$ & & ,538 & \\
\hline $\begin{array}{l}18 \text { Kullandığım operatör, müşteriyle iletişimi kolaylaştırmak için an- } \\
\text { laşılabilir bir şekilde konuşmaktadır. }\end{array}$ & & ,504 & \\
\hline 3Kullandığım operatör, sempatik ve güven verici olmaktadır. & & & ,823 \\
\hline $\begin{array}{l}\text { 4Kullandığım operatör, devamlı olarak nazik, hoş ve samimi olmak- } \\
\text { tadır. }\end{array}$ & & & ,736 \\
\hline 2Kullandığım operatör, müşterinin özel isteklerini anlamaktadır. & & & ,732 \\
\hline 5Kullandiğım operatör, müşteriyi özel hissettirmektedir. & & & ,580 \\
\hline $\begin{array}{l}\text { 1Kullandığım operatör, müşterinin talebine yanıt verme ve yardım et- } \\
\text { mede istekli } \\
\text { olmaktadır. }\end{array}$ & & & ,660 \\
\hline $\begin{array}{l}\text { 6Kullandığım operatör, müşteriye karşı yardımsever ve bireysel olarak } \\
\text { dikkatini } \\
\text { vermektedir. }\end{array}$ & & & ,624 \\
\hline Cronbach $\alpha$ Değeri & 882 & ,921 & 886 \\
\hline Açıklanan Varyans & $\% 17,972$ & $\% 24,212$ & $\% 17,743$ \\
\hline Toplam Açılanan Varyans & & $\% 59,927$ & \\
\hline
\end{tabular}

Tablo 3'te faktör analizinin sonucunda ortaya çıkan faktörler ve bu faktörlerin toplam varyansın ne kadarını açıkladığı görülmektedir. Buna göre, 1. faktör varyansın \% 17,972'ini, 2. faktör \%24,212'ünü ve 3. faktör \% 17,743'sini açıklamaktadır. Ölçeğin İlişkisel Pazarlamanın üç faktörlü olarak açıklama düzeyi ise \%59,927 dir. Ölçekteki faktörlerin güvenilirlik (iç tutarlılık) 
Baran, A. (2017). The effect of relationship marketing in the context of trust, communication and empathy to customer based brand equity: An application on GSM sector users. International Journal of Social Sciences and Education Research, 3(2), 361-378.

katsayıları ise sırasıyla; Güven: 0,882, İletişim: 0, 921 ve Empati: 0, 886 olarak bulunmuştur.

Araştırmaya dahil edilen değişkenler arasında istatistiki açıdan anlamlı ilişkilerin varolup olmadığını belirlemek amacıyla yapılan korelasyon analizi sonuçları Tablo 4'te gösterilmektedir. İlişkisel Pazarlama boyutlarından Empati, Güven ve İletişimin Marka Değeri boyutlarından Marka Çağrışımı, Marka Sadakati ve Algılanan Kalitenin üzerindeki etkisini belirlemeye yönelik yapılan bu araştırmada ilk olarak korelasyon analizi yapılarak değişkenler arasındaki anlamlı ilişkiler ve ilişkilerin yönü tespit edilmiştir.

Tablo 4. Korelasyon analizine ilişkin bulgular

\begin{tabular}{|c|c|c|c|c|c|c|c|c|c|}
\hline & $\mathbf{N}$ & Ort. & S.S & $\begin{array}{c}\text { Marka } \\
\text { Çağrıșımı }\end{array}$ & $\begin{array}{c}\text { Marka } \\
\text { Sadakati }\end{array}$ & $\begin{array}{c}\text { Algilanan } \\
\text { Kalite }\end{array}$ & Empati & Güven & İletişim \\
\hline $\begin{array}{l}\text { Marka } \\
\text { çağrışımı }\end{array}$ & 267 & 3,655 & 0,801 & 1 & ,238** &, $456 * *$ &, $376 * *$ &, $302 * *$ &, $386 * *$ \\
\hline $\begin{array}{l}\text { Marka sa- } \\
\text { dakati }\end{array}$ & 267 & 2,524 & 1,067 & & 1 &, $408 * *$ &, $121 *$ &, $144 *$ &, $211 * *$ \\
\hline $\begin{array}{l}\text { Algılanan } \\
\text { kalite }\end{array}$ & 267 & 3,556 & 0,757 & & & 1 &, $451 * *$ &, $471 * *$ &, $547 * *$ \\
\hline Empati & 267 & 3,568 & 0,857 & & & & 1 &, $694 * *$ &, $648 * *$ \\
\hline Güven & 267 & 3,544 & 0,832 & & & & & 1 &, $731 * *$ \\
\hline İletişim & 267 & 3,469 & 0,783 & & & & & & 1 \\
\hline
\end{tabular}

Korelasyon analizi sonuçlarına göre değişkenler arasındaki ilişki incelenmiştir. Araştırmada yer alan tüm değiş̧enlerin arasında $(\mathrm{p}<0,01)$ anlam düzeyinde çift yönlü ilişkilerin olduğu ortaya çıkmıştır. Tablo 4'te yer alan pearson korelasyon katsayılarına bakıldığında İlişkisel Pazarlama boyutlarından Empati, Güven ve İletişimin Marka Değeri boyutlarından Marka Çağrışımı, Marka Sadakati ve Algılanan Kalitenin üzerindeki anlamlı ve pozitif yönlü ilişki içinde olduğu, en güçlü ilişkinin ise İlişkisel Pazarlama boyutlarından İletişimin ile Marka Değeri boyutlarından Algılanan Kalite (r: 0,547; $<<0,01)$ arasında olduğu görülmektedir. Yani, katılımcıların iletişim algisı arttıkça algılanan kalite düzeyleri de artacaktır.

\subsection{Regresyon analizi ve hipotezlerin test edilmesi}

Araştırma hipotezlerini test etmek için üç farklı regresyon analizi gerçekleştirilmiştir. Hipotezleri test etmek için Forward Selection yöntemi ile çoklu regresyon analizleri yapılmış ve analiz sonuçları $\alpha=0,01$ ve $\alpha=0,05$ anlamlılık düzeylerine göre değerlendirmeye tabi tutulmuştur. Araştırma kapsamında oluşturulan hipotezlerin 5'i desyeklenirken 4'ünün de desteklenmediğ i sonucuna ulaşılmıştır. Hipotezleri test etmek için yapılan çoklu regresyon analizi sonuçları Tablo 5, Tablo 6 ve Tablo 7'de gösterilmektedir.

Bağımlı değişkenin marka değeri boyutlarından marka çağrışımı, bağımsız değişkenin ilişkisel pazarlama boyutları olan güven, iletişim ve empati olduğu çoklu regresyon analizi sonuçları Tablo 5 'de görüldüğ ̈̈ gibidir. F istatistiği analiz sonucunda oluşan iki modelinde anlamlı olduğunu göstermektedir. Forward Selection yöntemine göre yapılan çoklu regresyon analizinde modeli önemli derecede etkilemeyen değişkenler modelden çıkarılmıştır .Analiz sonucunda etkili olmayan güven boyutu istatistiksel olarak anlamsız çıktığ için $(p>0,05)$ modelden çıkarılmıştır. Tabloda görüldüğü gibi marka değeri boyutlarından marka çağrışımındaki değişmeyi açıklayan iletişim faktörünün 0,250 ve empati faktörünün 0,203 değeriyle istatistiki olarak anlamlı oldukları tespit edilmiştir. $\mathrm{Bu}$ doğrultuda araştırma kapsamında oluşturulan " $\mathrm{H}_{2}$ : İlşikisel Pazarlama boyutlarından İletişim, Marka Çağrışımını pozitif yönde ve anlamlı olarak etkilemektedir" ve 
Baran, A. (2017). Güven, iletişim ve empati bağlamında ilişkisel pazarlamanın tüketici temelli marka değerine etkisi: GSM operatör kullanıcıları üzerinde bir uygulama. International Journal of Social Sciences and Education Research, 3(2), 361-378.

" $\mathrm{H}_{3}$ : İlşikisel Pazarlama boyutlarından Empati, Marka Çağrışımlarını pozitif yönde ve anlamlı olarak etkilemektedir" hipotezlerinin desteklendiği görülmektedir. Ancak " $\mathrm{H}_{1}$ : İlşikisel Pazarlama boyutlarından Güven, Marka Çağnışımlarını pozitif yönde ve anlamlı olarak etkilemektedir" hipotezi desteklenmemektedir.

Tablo 5. İlişkisel pazarlama boyutlarının marka çağrışımı üzerindeki etkisine yönelik çoklu regresyon analizi bulguları

\begin{tabular}{|c|c|c|c|c|c|c|c|}
\hline Model & $\mathbf{R}$ & $\mathbf{R}^{2}$ & S.H. & \multicolumn{2}{|c|}{$\mathbf{F}$} & \multicolumn{2}{|c|}{$\mathbf{P}$} \\
\hline 1 & 0,386 & 0,149 & 0,740 & \multicolumn{2}{|c|}{46,31} & \multicolumn{2}{|c|}{0,000} \\
\hline 2 & 0,420 & 0,176 & 0,729 & \multicolumn{2}{|c|}{28,23} & \multicolumn{2}{|c|}{0,000} \\
\hline \multicolumn{2}{|r|}{ Model } & B & S.H. & Beta & $\mathbf{t}$ & $\mathbf{p}$ & D-W \\
\hline \multirow{2}{*}{1} & Sabit Terim & 2,288 & 0,206 & - & 11,105 & 0,000 & \\
\hline & İletişim & 0,394 & 0,058 & 0,386 & 6,805 & 0,000 & \\
\hline \multirow{3}{*}{2} & Sabit Terim & 2,062 & 0,217 & - & 9,509 & 0,000 & \multirow{3}{*}{1,864} \\
\hline & İletişim & 0,250 & 0,075 & 0,245 & 3,340 & 0,001 & \\
\hline & Empati & 0,203 & 0,069 & 0,217 & 2,966 & 0,003 & \\
\hline
\end{tabular}

İlk modelde ilişkisel pazarlama boyutlarında iletişim marka değeri boyutlarında marka çağrışımını \%14'ünü açıklamaktadır. Oluşan ikinci modelde ise iletişim ve empati ile mark çağrışımı arasında pozitif yönlü bir ilişki olduğu tespit edilmiştir. Bu iki değişkenin marka çağrışımı üzerindeki değişimin \%17'isini açıkladığı sonucuna ulaşılmıştır. Bu modele göre kurulacak regresyon modeli; Marka Çağrışımı $=2,062+($ İletişim X 0,250) $+($ Empati X 0,203)

Tablo 6. İlişkisel Pazarlama Boyutlarının Marka Sadakati Üzerindeki Etkisine Yönelik Çoklu Regresyon Analizi Bulguları

\begin{tabular}{|c|l|c|c|c|c|c|c|}
\hline Model & $\mathbf{R}$ & $\mathbf{R}^{2}$ & S.H. & \multicolumn{2}{|c|}{$\mathbf{F}$} & \multicolumn{2}{|c|}{ P } \\
\hline \multirow{2}{*}{1} & 0,211 & 0,044 & 1,045 & \multicolumn{2}{|c|}{12,337} & \multicolumn{2}{|c|}{0,001} \\
\hline \multicolumn{2}{|c|}{ Model } & $\mathbf{B}$ & S.H. & Beta & $\mathbf{t}$ & $\mathbf{p}$ & D-W \\
\hline \multirow{2}{*}{1} & Sabit Terim & 1,528 & 0,291 & - & 5,254 & 0,000 & \multirow{2}{*}{1,901} \\
\cline { 2 - 8 } & İletişim & 0,287 & 0,082 & 0,211 & 3,512 & 0,001 & \\
\hline
\end{tabular}

Bağımlı değişkenin marka değeri boyutlarından marka sadakati, bağımsız değişkenin ilişkisel pazarlama boyutları olan güven, iletişim ve empati olduğu çoklu regresyon analizi sonuçları Tablo 6'da görüldügü gibidir. F istatistiği analiz sonucunda oluşan tek modelin anlamlı olduğunu göstermektedir. Forward Selection yöntemine göre yapılan çoklu regresyon analizinde modeli önemli derecede etkilemeyen değişkenler modelden çıkarılmıştır. Analiz sonucunda etkili olmayan güven ve empati boyutları istatistiksel olarak anlamsız çıtığı için ( $\mathrm{p}>0,05)$ modelden çıkarılmıştır. Tabloda görüldüğü gibi marka değeri boyutlarından marka sadakatindeki değişmeyi açıklayan iletişim faktörünün 0,287 değeriyle istatistiki olarak anlamlı oldukları tespit edilmiştir.. 
Baran, A. (2017). The effect of relationship marketing in the context of trust, communication and empathy to customer based brand equity: An application on GSM sector users. International Journal of Social Sciences and Education Research, 3(2), 361-378.

$\mathrm{Bu}$ doğrultuda araştırma kapsamında oluşturulan " $\mathrm{H}_{5}$ : İlşikisel Pazarlama boyutlarından İletişism, Marka Sadakatini pozitif yönde ve anlamlı olarak etkilemektedir" hipotezi desteklenirken " $\mathrm{H}_{4}$ : İlşikisel Pazarlama boyutlarından Güven, Marka Sadakatini pozitif yönde ve anlamlı olarak etkilemektedir" ve "H : İlşikisel Pazarlama boyutlarından Empati, Marka Sadakatini pozitif yönde ve anlamlı olarak etkilemektedir" hipotezleri desteklenmemektedir.

Oluşan modelde ilişkisel pazarlama boyutlarından iletişimin marka değeri boyutlarında marka sadakatinin \%4'ünü açıkladığı görülmektedir. Bu modele göre kurulacak regresyon modeli; Marka Sadakati $=1,528+($ İletişîm X 0,287)

Tablo 7. İlişkisel pazarlama boyutlarının algılanan kalite üzerindeki etkisine yönelik çoklu regresyon analizi bulguları

\begin{tabular}{|c|c|c|c|c|c|c|c|}
\hline Model & $\mathbf{R}$ & $\mathbf{R}^{2}$ & S.H. & \multicolumn{2}{|c|}{$\mathbf{F}$} & \multicolumn{2}{|c|}{$\mathbf{P}$} \\
\hline 1 & 0,547 & 0,299 & 0,634 & \multicolumn{2}{|c|}{113,214} & \multicolumn{2}{|c|}{0,000} \\
\hline 2 & 0,532 & 0,315 & 0,628 & \multicolumn{2}{|c|}{60,840} & \multicolumn{2}{|c|}{0,000} \\
\hline \multicolumn{2}{|r|}{ Model } & B & S.H. & Beta & $\mathbf{t}$ & $\mathbf{p}$ & D-W \\
\hline \multirow{2}{*}{1} & Sabit Terim & 1,723 & 0,177 & - & 9,758 & 0,000 & \multirow{2}{*}{-} \\
\hline & İletişim & 0,528 & 0,050 & 0,547 & 10,640 & 0,000 & \\
\hline \multirow{3}{*}{2} & Sabit Terim & 1,560 & 0,187 & - & 8,350 & 0,000 & \multirow{3}{*}{2,005} \\
\hline & İletişim & 0,424 & 0,065 & 0,439 & 6,570 & 0,000 & \\
\hline & Empati & 0,147 & 0,059 & 0,167 & 2,496 & 0,013 & \\
\hline
\end{tabular}

Bağımlı değişkenin marka değeri boyutlarından Algılanan Kalite, bağımsız değişkenin ilişkisel pazarlama boyutları olan güven, iletişim ve empati olduğu çoklu regresyon analizi sonuçları Tablo 7'de görüldüğü gibidir. F istatistiği analiz sonucunda oluşan iki modelinde anlamlı olduğunu göstermektedir. Forward Selection yöntemine göre yapılan çoklu regresyon analizinde modeli önemli derecede etkilemeyen değişkenler modelden çıkarılmıştır. Analiz sonucunda etkili olmayan güven boyutu istatistiksel olarak anlamsız çıktığı için $(p>0,05)$ modelden çıkarılmıştır. Tabloda görüldüğü gibi marka değeri boyutlarından Algılanan kalitedeki değişmeyi açıklayan iletişim faktörünün 0,424 ve empati faktörünün 0,147 değeriyle istatistiki olarak anlamlı oldukları tespit edilmiştir. Bu doğrultuda araştırma kapsamında oluşturulan " $\mathrm{H}_{8}$ : İlşikisel Pazarlama boyutlarından İletişim, Algılanan Kaliteyi pozitif yönde ve anlamlı olarak etkilemektedir" ve "H${ }_{9}$ : İlşikisel Pazarlama boyutlarından Empati, Algılanan Kaliteyi pozitif yönde ve anlamlı olarak etkilemektedir" hipotezlerinin desteklendiği görülmektedir. Ancak " $\mathrm{H}_{7}$ : İlşikisel Pazarlama boyutlarından Güven, Algılanan Kaliteyi pozitif yönde ve anlamlı olarak etkilemektedir" hipotezi desteklenmemektedir.

İlk modelde ilişkisel pazarlama boyutlarında iletişim marka değeri boyutlarında algılanan kaliteyi \%29'onu açıklamaktadır. Oluşan ikinci modelde ise iletişim ve empati ile algılanan kalite arasında pozitif yönlü bir ilişki olduğu tespit edilmiştir. Bu iki değişkenin algılanan kalite üzerindeki değişimin \%31'ini açıkladığı sonucuna ulaşılmıştır. Bu modele göre kurulacak regresyon modeli; Algılanan Kalite $=1,560+($ İletişim X 0,424) $+($ Empati X 0,147) 
Baran, A. (2017). Güven, iletişim ve empati bağlamında ilişkisel pazarlamanın tüketici temelli marka değerine etkisi: GSM operatör kullanıc1ları üzerinde bir uygulama. International Journal of Social Sciences and Education Research, 3(2), 361-378.

\section{Sonuç}

Günümüzde rekabetin arttı̆̆ 1 ve ürünlerin birbirine benzer olduğu bir zamanda müşterilerle etkili ilişkilerin sağlanması ve bu etkileşimle tüketici tarafından algılanan marka değerinin olumlu algılanmas1 ayırt edici unsurlarla fark yaratması rekabette avantaj1 elde edilmesine olanak sağlamaktadır. İlişkisel Pazarlama ile mevcut müşterileri sadık müşteri haline getirerek tüketiciyle uzun ilişkilerin kurulması, kuvvetlendirilmesi ve etkili şekilde yapılması tüketici tarafından algılanan marka değeriyle de pazar gücünü elde etmektedir. İşletmenin amacı müşterilerle az maliyete katlanarak uzun dönemli bir ilişkiyle kar sağlamasıdır. Bununla beraber tüketici tarafından algılanan kalite, marka çağrışımı ve marka sadakatiyle birliktelik sağlanarak hem markayı tüketici zihninde değerli hem de uzun vadeli müşteri yaşam boyu sağlanmış olur.

Çalışma sonucunda ilişkisel pazarlama boyutlarından İletişimin ve Empati marka değeri boyutlarından Marka Çağrışımı ve Algılanan Kalite üzerinde etkisi sonucuna ulaşırken marka sadakati üzerinde sadece iletişim boyutunun etkisi olduğu sonucuna ulaşmıştır. İletişimin marka değeri boyutları üzerinde önemli bir etkisinin olduğu ve müşterilerle uzun vadeli bir ilişkinin kurulmasında iletişimin hayati değere sahip olduğu görülmektedir. Müşterilerle etkili ilişki ve iletişim kanallarının kurulmasıyla ve işletmelerin kendilerini tüketicilerin yerine koyup empati yaparak müş̧eriyi dikkate alması algılanan marka değerini önemli derece etkilemektedir. Bunula beraber $\mathrm{T}$ Testi ile yapılan fark testleri sonucuna göre başka operatörlere geçmek istemeyen katılımcıların empati, güven, iletişim, algılanan kalite, marka sadakati ve marka çağrışımı düzeyleri geçmek isteyenlerden daha yüksektir. Sosyal medyada operatörlerinin hesabını takip eden kullanıcıların güven, iletişim ve algılanan kalite düzeylerinin daha yüksek olduğu sonucuna ulaşılmıştır. İnternetin gelişmesi ve tüketicilerin çevrimiçi olma sürelerinin artmasıyla sosyal ağlarda etkili iletişimin kurulması marka değerini artırmaktadır.

Çalışma sonucunda ilişkisel pazarlamanın marka değeri üzerinde etkisi olduğu sonucuna ulaşılmıştır. Literatürde yapılan çalışmalar Aaker ve Jacobson (1994); Wolter (2009); Jesri vd. (2013); Abeysekera and Wickramasinghe (2013); Ukkwatte and Abeysekera (2015); Yoganathan (2015) çıkan sonucumuzu destekler niteliktedir. Geleceğe yönelik yapılacak çalışmalar için farklı örneklem gruplarında ve sektörlerde tekrarlanması ile daha ayrıntılı ve genellenebilir sonuçlara ulaşılabilir.

\section{Kaynakça}

Aaker, D. A. (1991). Managing Brand Equity: Capitalizing on the Value of a Brand Name. New York: The Free Press.

Abdullah, F., \& Kanyan, A. (2012). Identifying and Managing The Dimensions of Relationship Marketing for The Foodservice Industry. 3rd International Conference On Business and Economic, 1254-1270, 12-13 March, Indonesia

Avcilar, M. Y. (2008). Tüketici Temelli Marka Değerinin Ölçümü. Ç.Ü. Sosyal Bilimler Enstitüsü Dergisi, $17(1), 11-30$

Ayas, N. (2012). Marka Değeri Algılamalarının Tüketici Satın Alma Davranışı Üzerine Etkisi. Girişimcilik ve Kalkinma Dergisi, (7:1), 163-183

Doney, P. M. \& Cannon, J.P. (1997). An Examination of the Nature of Trust in Buyer-Seller Relationships. Journal of Marketing, 61, 35-51.

Erdoğan, B. Z. (2009) Pazarlama: Küresel Krizin Suçlusu mu, Kurtarıcısı mı?. Tüketici ve Tüketim Araştırmaları Dergisi, 1(1), 41-51. 
Baran, A. (2017). The effect of relationship marketing in the context of trust, communication and empathy to customer based brand equity: An application on GSM sector users. International Journal of Social Sciences and Education Research, 3(2), 361-378.

Erdoğan, B. Z. \& Tolga T. (2009). Bir Pazarlama Aracı Olarak Sanal Topluluklar. Pazarlama ve Pazarlama Araştırmaları Dergisi, 4, 45-71

Flavian, C. \& Guinaliu, M. (2005). The Influence of Virtual Communities on Distribution Strategies in The Internet. International Journal of Retail \& Distribution Management, 33 (6), 405-425.

Grönroos, C. (1996). Relationship Marketing: Strategic and Tactical İmplications. Management Decion, 34: $5-14$.

Gülmez, M., \& Kitapçı, O. (2003). İlişkisel Pazarlamanın Gelişimi ve Yakın Geleceği. C. ̈̈. İktisadi ve Ídari Bilimler Dergisi, 4(2), 81-89

Haciefendioğlu, Ş., \& Nil, Ç. (2008). İlişkisel Pazarlamada Güven Unsuru ve Otel İşletmelerinde Uygulama. Kocaeli Üniversitesi Sosyal Bilimler Enstitüsü Dergisi, 16, 107-126.

Homburg, C., Klarmann, M. \& Schmitt, C. (2010). Brand awareness in business markets: When is it related to firm performance?. International Journal of Research in Marketing, 27, 201-212.

İlgüner, M. 2009). Marka Değeri, Başarının En Önemli Göstergesi. Çerçeve Dergisi, 168-174,

Keller, K. L.(1993). Conceptualizing, Measuring, and Managing Customer-Based Brand Equity. Journal of Marketing, 57(1), 1-22

Kiliç, H. Ö., \& B. Z. Erdoğan. (2016). Bir İlişkisel Pazarlama Aracı Olarak Bağlamsal Pazarlama: Formdakal Web Sitesi Örneği. İnsan ve Toplum Bilimleri Araştırmaları Dergisi, 5(3), 460-477.

Low, G. S., \& Charles W. L. (2000. The Measurement and Dimensionality of Brand Associations. Journal of Product \& Brand Management, 9(6), 350-368.

Morgan, R. M. \& Hunt. S. D. (1994). The Commitment-Trust Theory of Relationship Marketing. Journal of Marketing, 58(3), 20-38.

Pappu, R., Quester, P.G. \& Cooksey, R.W. (2006). Consumer-Based Brand Equity and Country-of-Origin Relationships. European Journal of Marketing, 40(5/6), 697-717.

Parasuraman, A., Valarie A. Zeithaml \& Leonard L. B. (1988). Servqual: A Multiple-Item Scale for Measuring Consumer Perceptions of Service Quality. Journal of Retailing, 64(1), 12-40

Selvi, M. S. (2007). İlişkisel Pazarlama: Stratejiler ve Teknikler, Detay Yayıncılık, Ankara

Sheth, J. N. \& Parvatıyar, A.(2000). Handbook of Relationship Marketing, Sage Publication, Ins, Printed in the USA

Sin, L.Y.M, Alan C.B.T., Aliver, H.M.Y., Raymond, P.M. C.; Jenny S.Y. L. \& Lorett B.Y. L. (2005). Relationship Marketing Orientation Scale Development and Cross-Cultural Validation. Journal Of Business Research, 58 (2), 185-194

Supphellen, M. (2000). Understanding Core Brand Equity:Guidelines for Indepth Elicitation of Brand Associations. International Journal of Market Research,42(3), 319-338

Torlak, Ö., Volkan D. \& Behçet Y. Ö., (2014). Marka Farkındalığı, Marka İmajı, Markadan Etkilenme ve Markaya Güvenin Marka Bağl1lığı Üzerindeki Görece Etkilerinin İncelenmesi: Turkcell Örneği. Bilgi Ekonomisi ve Yönetimi Dergisi, IX(I ), 147-161

Vazquez, R., Rio, A.B. \& Iglesias, V. (2002). Consumer-Based Brand Equity:Development and Validation of a Measurement Instrument. Journal of Marketing Management, 18(6), 27-48

Villajero, A. F., Rondan, F. J. \& Sanchez, M. J. (2009). Pazarlama Çalışmalarının Marka Bilinirliği ve Marka İmajı Üzerindeki Doğrudan ve Dolaylı Etkileri.The Brand Age Dergisi, Temmuz, 91-96.

Yoganathan, D., Jebarajakirthy, C. \& Thaichon, P. (2015). The İnfluence of Relationship Marketing Orientation on Brand Equity in Banks. Journal of Retailing and Consumer Services, 26, 14-22

Yurdakul, M. \& Dalkılıç, N. (2006). İlişkisel Pazarlama Anlayışının Sigorta Müşterilerinin Bağlılığı Üzerindeki Etkisi. Dumlupınar Üniversitesi Sosyal Bilimler Dergisi, 16, 255-270

Zeithaml V.A. (1988). Consumer Perceptions of Price, Quality, and Value: A Means-End Model and Synthesis of Evidence. Journal of Marketing, 52, 2-22. 
Baran, A. (2017). Güven, iletişim ve empati bağlamında ilişkisel pazarlamanın tüketici temelli marka değerine etkisi: GSM operatör kullanıcıları üzerinde bir uygulama. International Journal of Social Sciences and Education Research, 3(2), 361-378.

\section{Extended abstract in English}

Relationship marketing is based on the definition, maintenance and development of the wishes and objectives of all individuals in the relations that is established with consumers and other partners. Relationship marketing is an attempt to increase future product purchases of customers by affecting attitudes and behaviors of customers via create customer satisfaction and increase quality perception (Grönroos, 1996).

Relational marketing has become important in terms of ensuring loyalty and trust of the customers, as well as increasing marketing efficiency and productivity (Kılıç and Erdoğan, 2016). In this study, four dimensions of relational marketing which are trust, loyalty, communication and empathy will be discussed.

Customer based brand equity is defined by all of the components which have features such as its symbol and name of the brand that either increases or decreases the value of products and services which are presented to the customers as an abstract element created as a result of marketing activities (Aaker, 1991). Nonphysical equities of brand has reached a level that surpasses that level of physical equities (İlgüner, 2009). In Aaker (1991) model, brand equity dimensions are defined as brand loyalty, perceived quality, brand awareness and brand associations.

Relationship marketing and customer based brand equity; Relationship marketing focuses on long-term exchange relations. In this respect, brand loyalty one of brand equity components is an important element in establishing and maintaining long-lasting relationships (Torlak vd., 2014). Morgan and Hunt (1994) is determined that consumers' trust in the brand is a meaningful step towards establishing customer relationships over time. Various researches have shown that relationship marketing has an impact on brand equity (Aaker ve Jacobson (1994); Wolter (2009); Jesri vd. (2013); Abeysekera and Wickramasinghe (2013); Ukkwatte and Abeysekera (2015); Yoganathan (2015)).

Method; In the survey form that used in the research, brand equity scale was adapted from Aaker (1991)'s study. Relational marketing scale was arranged by adapting four dimensions from the study of Abdullah and Kanyan (2012).

Research population and sample; The main mass of our study consists of students who are actively educated at the faculty of Economics and Administrative Sciences at Dumlupinar University in the fall semester of 2016-2017 (DPU Student Affairs, 2016). Necessary analyzes were made on 267 questionnaires

Aims and constraints of the research; The purpose of the research is to determine the effect of relationship marketing dimensions on brand equity dimensions. In this direction, it is aimed to investigate what extent the relationship marketing dimensions have effect on brand equity dimensions perceived by the consumers. The biggest limitation of the research is that conducting the research with students from only faculty of a city make difficult to generalize the results.

Data selection tools of the research; The survey method which is the primary data collection method was used to collect the data required for the research. The face-to-face survey technique was used in the implementation of the questionnaire. The questionnaire prepared for the sample is consists of questions that will reveal the brand equity, relationship marketing and demographic 
Baran, A. (2017). The effect of relationship marketing in the context of trust, communication and empathy to customer based brand equity: An application on GSM sector users. International Journal of Social Sciences and Education Research, 3(2), 361-378.

findings.

Model and hypotheses of the research; In this section, we tried to explain relations between the variables shown in Figure 1 used in the research model which is the basis of our research and relations among them. Research hypotheses have been developed in this direction.

Figure 1. Research model

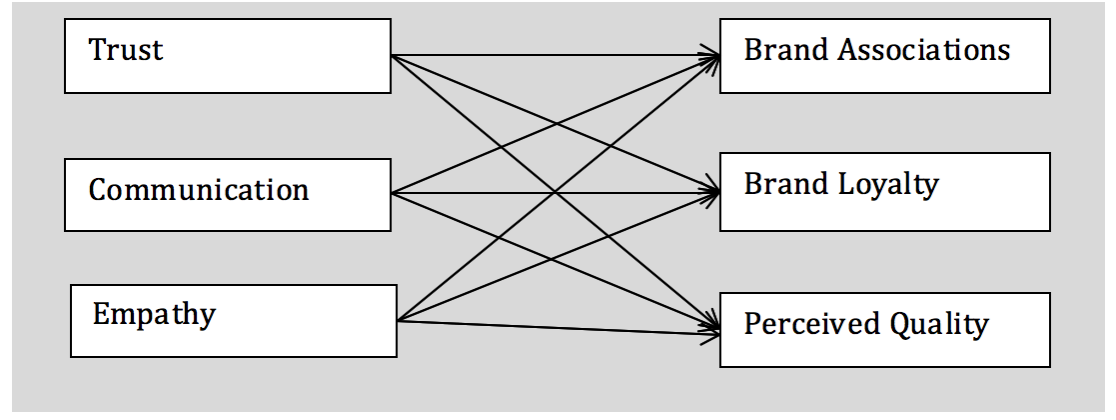

Hypotheses developed within the scope and purpose of the research;

$\mathrm{H}_{1}$ : Trust from relationship marketing dimensions positively and significantly influences brand associations.

$\mathrm{H}_{2}$ : Communication from relationship marketing dimensions positively and significantly influences brand associations.

$\mathrm{H}_{3}$ : Empathy from relationship marketing dimensions positively and significantly influences brand associations.

$\mathrm{H}_{4}$ : Trust from relationship marketing dimensions positively and significantly influences brand loyalty.

$\mathrm{H}_{5}$ : Communication from relationship marketing dimensions positively and significantly influences brand loyalty.

$\mathrm{H}_{6}$ : Empathy from relationship marketing dimensions positively and significantly influences brand loyalty.

$\mathrm{H}_{7}$ : Trust from relationship marketing dimensions positively and significantly influences perceived quality.

$\mathrm{H}_{8}$ : Communication from relationship marketing dimensions positively and significantly influences perceived quality.

$\mathrm{H}_{9}$ : Empathy from relationship marketing dimensions positively and significantly influences perceived quality.

Table 1. Reliability analysis of the scales

\begin{tabular}{|l|l|l|}
\hline Scales & Number of Expressions & Cronbach $\boldsymbol{\alpha}$ Value \\
\hline \multicolumn{3}{|c|}{ Dimensions of Relationship Marketing } \\
\hline Trust & 6 & 0,882 \\
\hline Communication & 12 & 0,921 \\
\hline Empathy & 6 & 0,886 \\
\hline \multicolumn{2}{|c|}{ Dimensions of Brand Equity } \\
\hline Brand Associations & 3 & 0,673 \\
\hline Brand Loyalty & 2 & 0,683 \\
\hline Perceived Quality & 5 & 0,778 \\
\hline
\end{tabular}


Baran, A. (2017). Güven, iletişim ve empati bağlamında ilişkisel pazarlamanın tüketici temelli marka değerine etkisi: GSM operatör kullanıcıları üzerinde bir uygulama. International Journal of Social Sciences and Education Research, 3(2), 361-378.

The degree of reliability of each dimension of scales is acceptable Brand awareness (0.348) from brand equity dimensions that were less than $65 \%$ confidentiality was not assessed.

Table 2. Findings related to correlation analysis

\begin{tabular}{|c|c|c|c|c|c|c|c|c|c|}
\hline & $\mathbf{N}$ & Mean & S.D & $\begin{array}{l}\text { Brand } \\
\text { Associations }\end{array}$ & $\begin{array}{l}\text { Brand } \\
\text { Loyalty }\end{array}$ & $\begin{array}{l}\text { Perceived } \\
\text { Quality }\end{array}$ & Empathy & Trust & $\begin{array}{l}\text { Communic } \\
\text { ation }\end{array}$ \\
\hline $\begin{array}{l}\text { Brand } \\
\text { Associations }\end{array}$ & 267 & 3,655 & 0,801 & 1 &, $238 * *$ &, $456 * *$ &, $376 * *$ &, $302 * *$ &, $386 * *$ \\
\hline Perceived Quality & 267 & 3,556 & 0,757 & & & 1 &, $451 * *$ &, $471 * *$ &, $547 * *$ \\
\hline Empathy & 267 & 3,568 & 0,857 & & & & 1 &, $694 * *$ &, $648 * *$ \\
\hline Trust & 267 & 3,544 & 0,832 & & & & & 1 &, $731 * *$ \\
\hline
\end{tabular}

According to the results of the correlation analysis, the relation between the variables was examined. It was found that there were two-way relations in $\mathrm{p}<0,01$ meaning level among all the variables in the research.

Testing Regression Analysis and Hypotheses; Three different regression analyzes were performed to test the research hypotheses. To test the hypotheses, multiple regression analyzes were performed by using Forward Selection method and the analysis results were evaluated according to the significance levels $\alpha=0,01$ and $\alpha=0,05$. The results of multiple regression analysis to test hypotheses are shown in Table 3, Table 4 and Table 5.

Table 3. Findings of multiple regression analysis about the effect of relationship marketing dimensions on brand associations

\begin{tabular}{|c|c|c|c|c|c|c|c|}
\hline Model & $\mathbf{R}$ & $\mathbf{R}^{2}$ & S.E. & \multicolumn{2}{|c|}{$\mathbf{F}$} & \multicolumn{2}{|c|}{ Sig. } \\
\hline 1 & 0,386 & 0,149 & 0,740 & \multicolumn{2}{|c|}{46,31} & \multicolumn{2}{|c|}{0,000} \\
\hline 2 & 0,420 & 0,176 & 0,729 & \multicolumn{2}{|c|}{28,23} & \multicolumn{2}{|c|}{0,000} \\
\hline \multicolumn{2}{|l|}{ Model } & B & S.E. & Beta & $\mathbf{t}$ & Sig. & D-W \\
\hline \multirow{2}{*}{1} & Constant Term & 2,288 & 0,206 & - & 11,105 & 0,000 & \multirow{2}{*}{-} \\
\hline & Communication & 0,394 & 0,058 & 0,386 & 6,805 & 0,000 & \\
\hline \multirow{3}{*}{2} & Constant Term & 2,062 & 0,217 & - & 9,509 & 0,000 & \multirow{3}{*}{1,864} \\
\hline & Communication & 0,250 & 0,075 & 0,245 & 3,340 & 0,001 & \\
\hline & Empathy & 0,203 & 0,069 & 0,217 & 2,966 & 0,003 & \\
\hline
\end{tabular}

According the results of analysis, trust dimension that is uneffective was removed from the model because it was statistically insignificant $(p>0,05)$. As it is seen in the table, it is found that the communication factor which explains the change in brand associations from the brand equity dimensions is statistically meaningful with 0,250 and empathy factor 0,203 values. In this direction, when $\mathrm{H}_{2}$ and $\mathrm{H}_{3}$ hypotheses are supported, $\mathrm{H}_{1}$ hypothesis is not supported. 
Baran, A. (2017). The effect of relationship marketing in the context of trust, communication and empathy to customer based brand equity: An application on GSM sector users. International Journal of Social Sciences and Education Research, 3(2), 361-378.

Table 4. Findings of multiple regression analysis about the effect of relationship marketing dimensions on brand loyalty

\begin{tabular}{|c|c|c|c|c|c|c|c|}
\hline Model & $\mathbf{R}$ & $\mathbf{R}^{2}$ & S.E. & \multicolumn{2}{|c|}{ F } & \multicolumn{2}{|c|}{ Sig. } \\
\hline \multirow{2}{*}{1} & 0,211 & 0,044 & 1,045 & \multicolumn{2}{|c|}{12,337} & \multicolumn{2}{|c|}{0,001} \\
\hline \multirow{2}{*}{ Model } & & $\mathbf{B}$ & S.E. & Beta & $\mathbf{t}$ & Sig. & D-W \\
\hline \multirow{2}{*}{$\mathbf{1}$} & Constant Term & 1,528 & 0,291 & - & 5,254 & 0,000 & \multirow{2}{*}{1,901} \\
\cline { 2 - 8 } & Communication & 0,287 & 0,082 & 0,211 & 3,512 & 0,001 & \\
\hline
\end{tabular}

As it is seen in the table, it is found that the communication factor explaining the change in brand loyalty from the brand equity dimensions is statistically meaningful with 0.287 value. In this direction, $\mathrm{H}_{4}$ and $\mathrm{H}_{6}$ hypotheses are not supported when the $\mathrm{H}_{5}$ hypothesis formed within the scope of the research is supported.

Table 5. Findings of multiple regression analysis about the effect of relationship marketing dimensions on perveived quality

\begin{tabular}{|c|l|c|c|c|c|c|c|}
\hline Model & $\mathbf{R}$ & $\mathbf{R}^{\mathbf{2}}$ & S.E. & \multicolumn{2}{|c|}{$\mathbf{F}$} & \multicolumn{2}{|c|}{ Sig. } \\
\hline \multirow{2}{*}{1} & 0,547 & 0,299 & 0,634 & 113,214 & \multicolumn{2}{|c|}{0,000} \\
\hline 2 & 0,532 & 0,315 & 0,628 & \multicolumn{2}{|c|}{60,840} & \multicolumn{2}{|c|}{0,000} \\
\hline \multirow{2}{*}{ Model } & $\mathbf{B}$ & S.E. & Beta & $\mathbf{t}$ & Sig. & \multirow{2}{*}{ D-W } \\
\hline \multirow{2}{*}{$\mathbf{1}$} & Constant Term & 1,723 & 0,177 & - & 9,758 & 0,000 & \\
\cline { 2 - 8 } & Communication & 0,528 & 0,050 & 0,547 & 10,640 & 0,000 & \\
\hline \multirow{2}{*}{$\mathbf{2}$} & Constant Term & 1,560 & 0,187 & - & 8,350 & 0,000 & \\
\cline { 2 - 8 } & Communication & 0,424 & 0,065 & 0,439 & 6,570 & 0,000 & 2,005 \\
\cline { 2 - 8 } & Empathy & 0,147 & 0,059 & 0,167 & 2,496 & 0,013 & \\
\hline
\end{tabular}

As seen in the table, it was found that the communication factor explaining the change in perceived quality was statistically meaningful with 0,414 value and the empathy factor 0,147 value. In this direction, the hypothesis $\mathrm{H}_{7}$ is not supported when the hypotheses $\mathrm{H}_{8}$ and $\mathrm{H}_{9}$ are supported.

Conclusion; As a the result of research, it is reached that while communication and empathy from the dimensions of relationship marketing have effect on brand associations and the perceived quality from the dimensions of brand equity, only communication dimension of relationship marketing has an effect on brand loyalty. It is seen that communication has an important influence on brand equity dimensions. Moreover, it has a vital value in establishing a long-term relationship with customers. Establishing effective relationships and communication channels and considering customers by empathising with them influences the perceived brand equity significantly. In addition, according to the results of difference test that is made with T-test, the degree of empathy, trust, communication, perceived quality, brand loyalty and brand associations of participants who 
Baran, A. (2017). Güven, iletişim ve empati bağlamında ilişkisel pazarlamanın tüketici temelli marka değerine etkisi: GSM operatör kullanıc1ları üzerinde bir uygulama. International Journal of Social Sciences and Education Research, 3(2), 361-378.

did not want to transfer to other operators are higher than participants who willing to. It is found that users who follow their operator's social media account have higher degree of trust, communication and perceived quality. Establishing effective communication in social networks through the development of the Internet and the boost in the online time of consumers increase brand equity.

The result of the research revealed that relationship marketing has an impact on brand equity. Studies in the literature which are Aaker and Jacobson (1994); Wolter (2009); Jesri et al. (2013); Abeysekera and Wickramasinghe (2013); Ukkwatte and Abeysekera (2015); Yoganathan (2015) supports research's outcome. Future research have more detailed and generalizable results, If the research can be repeated in different samples and sectors. 